\title{
PENGARUH RASIO-RASIO KEUANGAN TERHADAP \\ KINERJA KEUANGAN BANK SYARIAH PERIODE \\ TAHUN 2010-2012 \\ (STUDI KASUS PADA BPRS ARTHA SURYA BAROKAH)
}

\author{
Nolita Dwi Arini \\ Fatmasari Sukesti \\ Program Studi Akuntansi \\ Fakultas Ekonomi \\ Universitas Muhammadiyah Semarang
}

\begin{abstract}
Bank is a financial institution whose main activity is to receive deposits from the public and distribute to third parties to obtain and deliver services in payment traffic. Reality show no economic indicators that can be developed without the help of banking institutions. Therefore, the bank holds a strategic role in the economy. The existence of the banking sector in Indonesia is divided into two types of banks, ie commercial banks and rural banks.

The population in this study is the overall financial statement SRB Surya Artha Barokah Semarang. Samples taken in this study is the financial statement SRB Surya Artha Barokah 2010-2012. Analysis tool used is multiple linear regression. The results showed that the hypothesis test using the $F$ test showed that the CAMEL variables simultaneously affect the bank's financial performance. Hypothesis testing using t-test showed that there are significant between the RWA, $C A R, C A R, K A P, P P A P, P M, R O A$, Cash Ratio, on financial performance. The higher RWA, CAR, CAR, KAP, PPAP, PM, ROA, the higher the financial performance of BPR Syariah Surya Artha Barokah Semarang. Hypothesis testing using t-test showed that there is no influence between the Cash Ratio and LDR on financial performance. Cash Ratio and the higher the LDR then it will not affect the financial performance of BPR Syariah Barokah Arta Surya Semarang.
\end{abstract}

Key word : ATMR, KPMM, CAR, KAP, PPAP, PM, ROA, Cash Ratio and financial performance 
Latar Belakang Masalah

Bank merupakan lembaga keuangan yang kegiatan utamanya adalah menerima simpanan dari masyarakat dan menyalurkan kembali kepada pihak ketiga untuk memperoleh dan menyediakan jasajasa dalam lalulintas pembayaran. Kenyataan menunjukkan tidak ada indikator ekonomi yang dapat berkembang tanpa bantuan lembaga perbankan. Oleh karena itu, bank memegang peranan yang sangat strategis dalam perekonomian. Keberadaan dunia perbankan di Indonesia di bagi menjadi dua jenis bank, yaitu bank umum dan bank perkreditan rakyat. Bank perkreditan rakyat merupakan salah satu pendukung perkembangan perekonomian Indonesia, terutama untuk kegiatan usaha mikro, kecil dan menengah serta sektor informal. Peran BPR dalam pemberian kredit bagi usaha mikro, kecil, dan menengah ini dapat membantu menciptakan lapangan pekerjaan, pemerataan pendapatan dan pemerataan kesempatan berusaha di Indonesia.

BPR Syariah sebagai salah satu lembaga keuangan yang bergerak di bidang bisnis jasa keuangan tentunya memiliki tujuan, baik tujuan jangka pendek, maupun tujuan jangka panjang. Tujuan jangka pendek adalah untuk memperoleh laba yang baik yang akan dicapai oleh BPR Syariah. Tujuan jangka panjang adalah untuk menjaga kelangsungan hidupnya. Untuk mencapai tujuan tersebut manajemen harus bekerja keras dengan pengelolaan yang baik. BPR Syariah sebagai lembaga keuangan harus betul-betul menjaga kepercayaan. Untuk menjaga kepercayaan tersebut BPR Syariah harus menjaga kesehatan perusahaannya. Tingkat kesehatan BPR Syariah adalah kinerja dan kualitas BPR Syariah dilihat dari faktor-faktor penting yang sangat berpenagruh bagi kelancaran, keberlangsungan, keberhasilan usaha BPR Syari'ah, baik jangka pendek, maupun jangka panjang (Buchori, 2001).

Berdasarkan uraian tersebut, maka penulis ingin mengadakan penelitian mengenai kinerja laporan keuangan bank syariah dengan judul "PENGARUH RASIO-RASIO KEUANGAN TERHADAP KINERJA KEUANGAN BANK SYARIAH DENGAN MENGGUNAKAN METODE CAMEL (Studi Kasus pada BPRS Artha Surya Barokah Semarang Periode Tahun 2006-2012). Rumusan Masalah

Berdasarkan latar belakang masalah diatas dapat dirumuskan permasalahan yang akan dipecahkan dalam penelitian ini yaitu sebagai berikut :

1. Bagaimana tingkat kesehatan keuangan bank ditinjau dari analisis CAMEL pada BPR Syariah Artha Surya Barokah Semarang tahun 2006-2012?

2. Bagaimana pengaruh rasiorasio keuangan terhadap kinerja keuangan bank?

\section{TINJAUAN PUSTAKA Bank Syariah}

Berdasarkan Undang-undang No.7 Tahun 1992 tentang perbankan sebagaimana telah diubah dengan Undang-undang No.10 Tahun 1998, jenis bank di Indonesia terdiri dari dua kelompok yaitu bank umum dan bank perkreditan rakyat (BPR). Dalam UU tersebut dijelaskan bahwa bank umum adalah bank yang 
melaksanakan kegiatan usaha secara konvensional atau berdasarkan prinsip syariah yang dalam kegiatannya memberikan jasa dalam lalu lintas pembayaran. Dalam menjalankan kegiatan usahanya bank umum dapat memilih satu dari tiga pilihan yaitu seluruhnya beroperasi secara konvensional, seluruhnya beroperasi secara syariah, atau melakukan kegiatan usaha secara konvensional sekaligus juga melakukan kegiatan usaha berdasarkan prinsip syariah (dual system bank) (Antonio, 2000).

Perbedaan antara bank syariah dengan bank konvensional terutama pada produk dan jasa perbankan yang ditawarkan. Bank syariah memiliki karakteristik antara lain tidak menggunakan sistem bunga, tetapi dengan menggunakan metode bagi hasil dan jual beli, bank syariah juga hanya memberikan pembiayaan pada kegiatan usaha yang halal, dan bank syariah wajib memiliki Dewan Pengawas Syariah (DPS). Sejak tahun 1990 (Lokakarya Bunga Bank dan Perbankan MUI 1921 Agustus 1990) MUI sudah memilih bahwa bunga bank itu memang haram. Karena itu MUI mengeluarkan bank tanpa bunga (Bank Muamalat Indonesia, didirikan tahun 1992). Perbedaan yang muncul sampai saat ini adalah apakah keharamannya mutlak atau tidak. Ada yang mengharamkannya mutlak, tetapi pendapat yang berkembang di MUI memilih bahwa keharamannya tidak mutlak, yaitu masih membolehkan bunga bank karena darurat (keterpaksaan). Ini dikarenakan bank syariah belum dapat membuka layanan di seluruh daerah di Indonesia (Antonio, 2000). Kinerja Bank
Kinerja keuangan adalah gambaran tentang setiap hasil ekonomi yang mampu diraih oleh perusahaan perbankan pada saat periode tertentu melalui aktivitasaktivitas perusahaan untuk menghasilkan keuntungan secara efesien dan efektif, yang dapat diukur perkembangannya dengan mengadakan analisis terhadap datadata keuangan yang tercermin dalam laporan keuangan. Untuk mengukur keberhasilan suatu perusahaan pada umumnya berfokus pada laporan keuangan disamping data data non keuangan lain yang bersifat sabagai penunjang. Informasi kinerja bermanfaat untuk memprediksi kapasitas perusahaan dalam manghasilkan arus kas dari sumber dana yang ada (Baraba, 1999).

\section{Kesehatan Keuangan Bank}

Kesehatan keuangan bank dapat diartikan sebagai kemampuan suatu bank untuk melakukan kegiatan operasional perbankkan secara normal seperti kemampuan menghimpun dana dari masyarakat, dari lembaga lain, dan dari modal sendiri, kemampuan mengelola dana, kemampuan untuk menyalurkan dana ke masyarakat, karyawan, pemilik modal, dan pihak lain, pemenuhan peraturan perbankkan yang berlaku dan mampu memenuhi semua kewajiban dengan baik dengan caracara yang sesuai dengan peraturan perbankkan yang berlaku.(Budi Santoso : 2006)

\section{Metode CAMEL}

Kesehatan atau kondisi keuangan dan non keuangan bank berdasarkan prinsip syariah merupakan kepentingan semua pihak terkait, baik pemilik manajemen bank, masyarakat pengguna jasa bank. Dalam melakukan penilaian terhadap kinerja bank, metode 
CAMEL adalah metode standar yang digunakan oleh bank sentral hampir di seluruh dunia. Bank sentral mempunyai kewajiban dan wewenang untuk menjaga dan mengendalikan bank-bank yang ada didalam industri perbankannya. Untuk melakukan kontrol terhadap kinerja maka bank sentral mewajibkan bank-bank untuk mengirimkan laporan keuangan secara berkala baik berupa laporan mingguan, triwulan, semester, maupun laporan tahunan. Ukuran untuk penilaian kesehatan bank syariah telah ditentukan oleh Bank Indonesia. Pengembangan Perbankan Syariah Indonesia (2002). Diantaranya terdapat pada Cetak Biru Pengembangan Perbankan Syariah Indonesia (2002). Berdasarkan ketentuan dalam Undang-undang tentang perbankan dan peraturan yang terdapat pada Cetak Biru Pengembangan Perbankan Syariah Indonesia, Bank Indonesia mengeluarkan peraturan Bank Indonesia nomor : 9/1/PBI/2007 yang mengatur tentang sistem penilaian tingkat kesehatan bank umum berdasarkan prinsip syariah (Bank Indonesia, 2002)

\section{a. Rasio Modal (Capital)}

Modal merupakan faktor yang sangat penting bagi perkembangan dan kemajuan bank serta upaya untuk tetap menjaga kepercayaan masyarakat. Bank Indonesia (BI) sebagai otoritas moneter menetapkan ketentuan mengenai kewajiban penyediaan modal minimum yang harus selalu dipertahankan setiap bank. Kecakupan modal merupakan faktor penting dalam bank dalam rangka pengembangan usaha dan menampung risiko kerugian. Bank
Indonesia mendapatkan kewajiban penyediaan modal minimum yang harus selalu dipertahankan oleh setiap bank sebagai suatu proporsi tertentu dari total ATMR. Ketentuan pemenuhan permodalan minimum bank disebut juga Capital Adequacy Ratio (CAR), ketentuan CAR adalah 8\%. Kecuali pada saat terjadi krisis moneter pada tahun 1998, ketentuan CAR diturunkan menjadi $4 \%$. Penurunan nilai CAR tersebut dimaksudkan untuk membantu kinerja tingkat kesehatan bank. Angka ini merupakan penyesuaian dari ketentuan yang berlaku secara internasional berdasarkan standar Bank for International Settlement (BIS), agar perbankan Indonesia dapat berkembang secara sehat dan memiliki kemampuan bersaing dengan bank-bank internasional (Nanda: 2006).

b. Rasio Kualitas Aktiva Produktif (Assets Quality)

Aktiva produktif sebagaimana di maksud dalam Surat Edaran Bank Indonesia No. 31/147/KEP/DIR tanggal 12 November 1998 adalah penanaman dana baik dalam rupiah atau valuta asing dalam bentuk kredit, surat berharga, penempatan antar bank, penyertaan, termasuk komitmen dan kontijensi pada transaksi rekening administratif. Kualitas aktiva produktif adalah semua aktiva dalam rupiah atau valas yang dimiliki oleh bank dengan maksud untuk memperoleh penghasilan sesuai dengan fungsinya, yaitu pemberian kredit, kepemilikan surat-surat berharga, dan penempatan dana kepada bank lain baik dari dalam 
maupun luar negeri terkecuali penanaman dana dalam bentuk giro atau penyertaan. (Dendawijaya:2009)

Dari definisi di atas dapat disimpulkan bahwa kualitas aktiva produktif adalah tolok ukur untuk menilai tingkat kemungkinan diterimanya kembali dana yang ditanamkan dalam aktiva produktif berdasarkan kriteria tertentu.

. Rasio Manajemen (Management) Menurut Stoner dalam T. Hani Handoko (2003), "Manajemen adalah proses perencanaan, pengorganisasian, pengarahan dan pengawasan usaha-usaha para anggota organisasi dan penggunaan sumber daya-sumber daya organisasi lainnya agar mencapai tujuan organisasi yang telah ditetapkan."

Menurut Luther Gulick dalam T. Hani Handoko (2003), "Manajemen adalah suatu bidang ilmu pengetahuan (scince) yang berusaha secara sistematis untuk memahami mengapa dan bagaimana manusia bekerjasama untuk mencapai tujuan dan membuat sistem kerjasama ini lebih bermanfaat bagi kemanusiaan."

\section{d. Rasio Rentabilitas (Earning)}

Menurut Kasmir (2008),"

Earning adalah merupakan kemampuan bank dalam meningkatkan labanya.

Analisis rasio rentabilitas bank adalah alat untuk menganalisis atau mengukur tingkat efisiensi usaha dan profitabilitas yang dicapai oleh bank yang bersangkutan. Selain itu, rasio-rasio dalam kategori ini dapat pula digunakan untuk mengukur tingkat kesehatan keuangan bank bank. (Dendawijaya:2009)

Menurut Munawir S. (2002), “ Rentabilitas adalah menunjukkan kemampuan perusahaan untuk menghasilkan laba selama periode tertentu." Rentabilitas adalah kemampuan bank untuk menghasilkan keuntungan yang wajar sesuai dengan line of business. Rentabilitas suatu bank dalam analisa CAMEL ini adalah meliputi besarnya rasio laba sebelum pajak diperoleh terhadap total asset (ROA), dan rasio beban operasional terhadap pendapatan operasional bank (BOPO).

\section{e. Rasio Likuiditas (Liquidity)}

Menurut Dendawijaya (2009), "Likuiditas adalah kemampuan bank dalam memenuhi kewajiban-kewajiban jangka pendeknya atau kewajiban yang sudah jatuh tempo."

Menurut Munawir S. (2002), "Likuiditas adalah menunjukkan kemaampuan suatu perusahaan untuk memenuhi kewajiban pada saat ditagih, perusahaan yang mampu memenuhi kewajiban keuangannya tepat pada waktunya berarti perusahan tersebut dalam keadaan likuid. Rasio likuiditas adalah kemampuan suatu bank dalam memenuhi kewajiban jangka pendeknya secara tepat waktu Suatu bank dapat dikatakan likuid, apabila bank bersangkutan mampu membayar semua hutangnya terutama hutang jangka pendek. Dalam hal ini yang dimaksud dengan hutang jangka pendek yang ada 
di bank antara lain adalah simpanan masyarakat yaitu seperti tabungan, giro, dan deposito.

Dikatakan likuid jika pada saat ditagih bank mamapu membayar. Kemudian bank juga harus dapat pula memenuhi semua permohonan kredit yang layak dibiayai. Dalam penelitian ini, rasio likuiditas yang digunakan adalah Loan to Deposit Ratio (LDR).
Kerangka konseptual merupakan pondasi utama untuk sepenuhnya proyek penelitian itu ditujukan, hal ini merupakan jaringan hubungan antar variabel yang secara logis diterangkan dan dikembangkan dari perumusan masalah yang telah diidentifikasikan melalui proses wawancara, observasi dan survey literatur, (Kuncoro, 2003). Secara sederhana kerangka konseptual didalam penelitian ini dapat dilihat dalam gambar berikut :

\section{Kerangka Pemikiran}

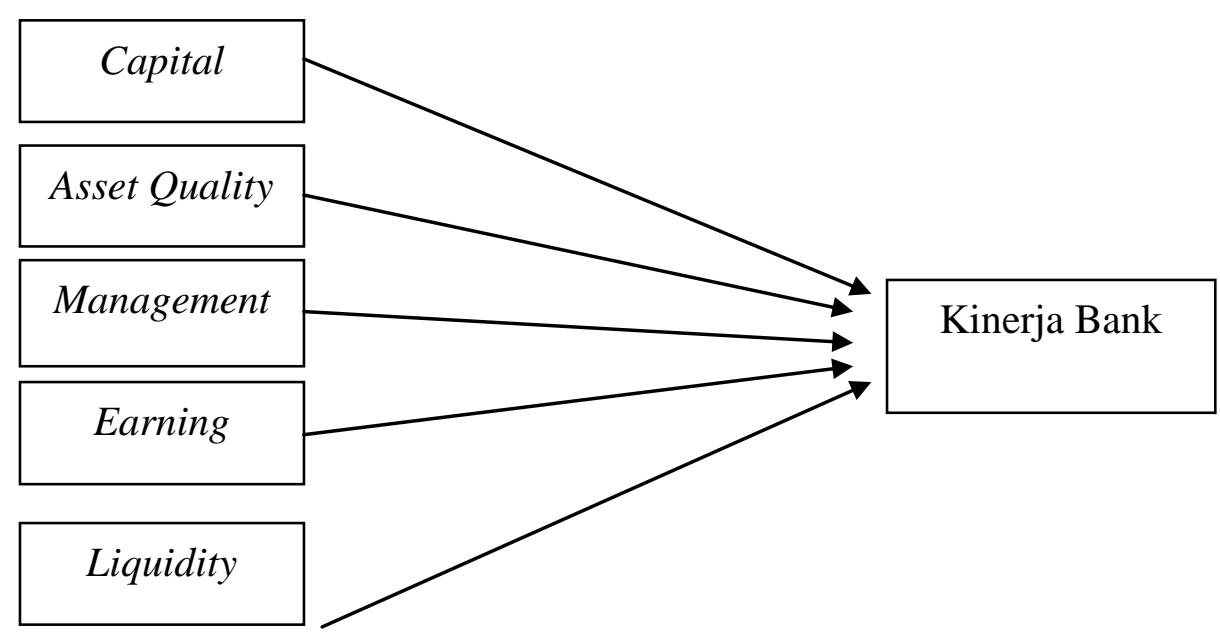

Gambar 2.1

Kerangka Pemikiran

\section{Hipotesis}

Hipotesis merupakan jawaban sementara terhadap rumusan masalah penelitian, oleh karena itu rumusan masalah penelitian biasanya disusun dalam bentuk pernyataan (Sugiyono, 2005).

Hipotesis dalam penelitian ini adalah:

$\mathrm{H}_{1} \quad=$ Permodalan berpengaruh positif terhadap Kinerja Bank.

$$
\begin{aligned}
& \mathrm{H}_{2}=\text { Kualitas Aktiva } \\
& \text { Produktif berpengaruh } \\
& \text { positif terhadap } \\
& \text { Kinerja Bank. } \\
& \mathrm{H}_{3} \quad=\text { Manajemen } \\
& \text { berpengaruh positif } \\
& \text { terhadap Kinerja Bank. } \\
& \mathrm{H}_{4} \quad=\text { Rentabilitas } \\
& \text { berpengaruh positif } \\
& \text { terhadap Kinerja Bank. } \\
& \mathrm{H}_{5}=\quad \text { Likuiditas } \\
& \text { berpengaruh positif }
\end{aligned}
$$


METODOLOGI PENELITIAN

Variabel Penelitian dan Devinisi Operasional

Penelitian ini dibatasi pada faktor-faktor yang mempengaruhi tingkat kesehatan BPR Syariah Artha Surya Barokah Semarang dengan tujuan untuk manghindari ketidakjelasan dalam membahas dan menganalisis permasalahan. Variabel yang dianalisis adalah sebagai berikut :

a) Rasio Modal (Capital)

b) Rasio Kualitas Aktiva

Produktif (Asset Quality)

c) Rasio Manajement

(Management)

d) Rasio Rentabilitas (Earning)

e) Rasio Likuiditas (Liquidity)

\section{Devinisi Operasional Variabel}

1. Permodalan

Faktor permodalan dihitung melalui rasio modal terhadap Aktiva Tertimbang Menurut Risiko (ATMR) atau yang lebih dikenal dengan perhitungan Capital Adequacy Ratio (CAR).

Perbandingan antara modal bank terhadap Aktiva Tertimbang Menurut risiko (ATMR) (Taswan, 2006).

a. Perhitungan ATMR

ATMR = Aktiva Neraca $\mathrm{X}$ Bobot Risiko

b. Pemenuhan kewajiban Penyediaan Modal Minimum (KPMM) $\mathrm{KPMM}=8 \% \mathrm{X}$ ATMR

c. Rasio Modal (CAR)

CAR merupakan perbandingan antara modal bank dengan Aktiva Tertimbang Menurut Risiko (ATMR).

$$
\begin{aligned}
& \text { CAR = } \\
& \frac{\text { Modal Bank }}{\text { ATMR }} \times 100 \%
\end{aligned}
$$

$1+\frac{\text { Rasio }}{0,1 \%} x 1=$ Nilai Kredit $\ldots$

Cara penilaian faktor permodalan dihitung berdasarkan kriteria sebagai berikut:

Rasio modal $8 \%$ dengan nilai kredit 81 diberi predikat sehat dan untuk setiap kenaikan $0,1 \%$ mulai $8 \%$ dengan nilai kredit ditambah 1 maksimum 100, setiap penurunan $0,1 \%$ dari $7,9 \%$ diberi predikat kurang sehat dengan nilai kredit 65 dikurangi 1.

2. Kualitas Aktiva Produktif Dalam melakukan penilaian terhadap komponen faktor kualitas asset didasarkan atas dua rasio yaitu

a. Kualitas Aktiva Produktif (KAP)

$$
\text { Ratio }
$$

$$
\begin{aligned}
& \frac{\text { AktivaProduktifyangdiklasifikasikan }}{\text { AktivaProduktif }} \\
& \text { Ratio } \\
& =\frac{50 \% \text { KL }+75 \% D+100 \% M}{2 \text { Aktiva Produktif! }} \\
& \text { Sumber: }
\end{aligned} \text { Taswan } 100 \%
$$


AktivaPemberian

Nilai Kredit adalah

1) Untuk rasio $22,5 \%$ atau lebih diberi nilai kredit 0

2) Untuk setiap penurunan $0,15 \%$ mulai dari $22,5 \%$ nilai kredit ditambah 1 dengan maksimum 100.

b. Perbandingan Penyisihan Penghimpunan Aktiva Produktif yang Dilakukan bentuk (PPAPYD)

$=\frac{\text { RPAP }}{P P A P W D !} \times 100 \%$ (2006)

Sumber : Taswan

Pemberian Nilai Kredit adalah

1) Untuk rasio $0 \%$ diberi nilai kredit 0

2) Untuk setiap kanaikan $1 \%$ mulai dari $0 \%$ nilai kredit ditambah 1 dengan nilai maksimum 100.

3. Faktor Manajemen

Faktor manajemen dalam penelitian menggunakan rumus laporan keuangan yaitu Profit Margin.

4. Faktor Rentabilitas

Dalam melakukan penilaian terhadap komponen faktor rentabilitaspeneliti menggunakan 2 rasio.

a) $\mathrm{ROA}$

$$
\frac{\text { Laba Bersih Sebelum Pajak }}{\text { Total Aktiva }} \times 100 \%
$$

Keterangan:
1) Untuk rasio $0 \%$ atau negatif diberi nilai kredit 0

2) Untuk setiap kenaikan $0,015 \%$ mulai dari $0 \%$ nilai kredit ditambahkan dengan nilai maksimum 100.

b) Biaya Operasional dibandingkan dengan Pendapatan Operasional(BOPO). BOPO

$=$ $\frac{\text { Total Beban Operasi }}{\text { Total Pendapatan Operasional }}$
Pemberian Nilai

Kredit, adalah:

1) Untuk rasio $100 \%$ atau lebih dari nilai kredit 0 .

2) Untuk setiap penurunan $0,08 \%$ nilai kredit ditambah 1 denganmaksimum 100.

5. Faktor Likuiditas

a. Perhitungan Cash Rasio:

$$
\begin{aligned}
& \text { Cash Rasio } \\
& =\frac{\text { Aktiva Lancar }}{\text { Hutang Lancar }}+
\end{aligned}
$$$$
100 \%
$$

Pemberian Nilai Kredit:

$\mathrm{NK}=($ Rasio $: 0,05) \mathrm{x}$ 1(maksimum 100)

Nilai Faktor:

Nilai Faktor $=$ Bobot ROA x NK

b. Perhitungan Rasio

LDR:

LDR

$$
=
$$
$\frac{\text { kredit yang diberikan }}{2 ! \text { dana yang diterima }} \times 100 \%$

Kredit: Perhitungan Nilai

$\mathrm{NK}=(115-$ Rasio $) \mathrm{x}$ 4(maksimum 100)

Nilai Faktor: 


\section{Nilai Faktor $=$ Bobot \\ LDR x NK}

\section{Penentuan Populasi dan Sampel}

Populasi adalah wilayah generalisasi yang terdiri atas obyek/subyek yang mempunyai kualitas dan karakteristik tertentu yang ditetapkan oleh peneliti untuk dipelajari dan kemudian ditarik kesimpulannya (Sugiyono, 2005). Populasi dalam penelitian ini adalah keseluruhan laporan keuangan BPRS Artha Surya Barokah Semarang.

Sampel adalah bagian dari jumlah dan karakteristik yang dimiliki oleh populasi tersebut (Sugiyono, 2005). Sampel yang diambil dalam penelitian ini adalah laporan keuangan BPRS Artha Surya Barokah tahun 2006-2012.

\section{Metode Analisis Data}

Metode

analisis

merupakan suatu metode yang digunakan penulis untuk menguraikan suatu objek berdasarkan unsur-unsur dalam suatu objek. Dalam hal ini penganalisaan data-data yang telah dikumpulkan untuk penulisan skripsi ini, penulis menggunakan metode deskriptif. Dimana metode deskriptif merupakan suatu metode dimana data dikumpulkan, diinterpretasikan, dianalisis sehingga memberikan keterangan yang lengkap bagi pemecahan permasalahan yang dihadapi.

Rumus rasio yang digunakan untuk menilai tingkat kesehatan keuangan BPRS untuk masing-masing faktor dan komponennya adalah sebagai berikut:
1. Permodalan

Faktor permodalan dihitung melalui rasio modal terhadap Aktiva Tertimbang Menurut Risiko (ATMR) atau yang lebih dikenal dengan perhitungan Capital Adequacy Ratio (CAR).

Perbandingan antara modal bank terhadap Aktiva Tertimbang Menurut risiko (ATMR) (Taswan, 2006).

a. Perhitungan ATMR

ATMR = Aktiva Neraca X Bobot Risiko

b. Pemenuhan kewajiban Penyediaan Modal Minimum (KPMM) $\mathrm{KPMM}=8 \% \mathrm{X}$ ATMR c. Rasio Modal (CAR) CAR merupakan perbandingan antara modal bank dengan Aktiva Tertimbang Menurut Risiko (ATMR). CAR

$\frac{\text { Modal Bank }}{\text { ATMR }} \times 100 \%$

Untuk menentukan

kriteria risiko

permodalan dapat menggunakan rumus sebagai berikut:

$1+\frac{\text { Rasio }}{0,1 \%} x 1=$ Nilai Kredit $\ldots$

Cara penilaian faktor permodalan dihitung berdasarkan kriteria sebagai berikut:

Rasio modal $8 \%$ dengan nilai kredit 81 diberi predikat sehat dan untuk setiap kenaikan $0,1 \%$ mulai $8 \%$ dengan nilai kredit ditambah 1 maksimum 100, setiap penurunan $0,1 \%$ dari $7,9 \%$ diberi predikat 
kurang sehat dengan nilai kredit 65 dikurangi 1.

2. Kualitas Aktiva Produktif Dalam melakukan penilaian terhadap komponen faktor kualitas asset didasarkan atas dua rasio yaitu

a. Kualitas Aktiva Produktif (KAP)

$$
\begin{aligned}
& \text { Ratio } \\
& = \\
& \text { Ratio } \\
& =\frac{50 \% K L+75 \% D+100 \% M}{2 \text { Aktiva Produktif } !} \times 100 \% \\
& \text { Sumber: Taswan } \\
& \text { (2006) } \\
& \text { Keterangan: } \\
& \mathrm{KL}=\text { Kurang } \\
& \text { Lancar } \\
& \mathrm{D}=\text { Diragukan } \\
& \mathrm{M}=\text { Macet } \\
& \text { Aktiva Produktif = } \\
& \text { Kredit yang diberikan } \\
& +\quad \text { Antar Bank } \\
& \text { AktivaPemberian } \\
& \text { Nilai Kredit adalah }
\end{aligned}
$$$$
\frac{\text { AktivaProduktifyangdiklasifikasikan }}{\text { AktivaProduktif }} \times 100 \%
$$

b. Perbandingan Penyisihan Penghimpunan Aktiva Produktif yang Dilakukan bentuk (PPAPYD)

$$
=\frac{\text { RPAP }}{P P A P W D !} \times 100 \%
$$$$
\text { (2006) }
$$

Pemberian Nilai Kredit adalah

3) Untuk rasio $0 \%$ diberi nilai kredit 0

4) Untuk setiap kanaikan $1 \%$ mulai dari $0 \%$ nilai kredit ditambah 1 dengan nilai maksimum 100.

c. Faktor

Manajemen

Penilaian

Faktor manajemen dalam penelitian ini menggunakan nilai Provit margin

d. Faktor Rentabilitas

Dalam melakukan penilaian terhadap komponen faktor rentabilitaspeneliti menggunakan 2 rasio.

c) $\mathrm{ROA}$

$$
\frac{\text { Laba Bersih Sebelum Pajak }}{\text { Total Aktiva }} \times 100 \%
$$

Keterangan:

1) Untuk rasio $0 \%$ atau negatif diberi nilai kredit 0

2) Untuk setiap kenaikan $0,015 \%$ mulai dari $0 \%$ nilai kredit ditambahkan dengan nilai maksimum 100.

d) Biaya Operasional dibandingkan dengan Pendapatan Operasional(BOPO). BOPO

$=$

$\frac{\text { Total Beban Operasi }}{\text { Total Pendapatan Operasional }} \times 100 \%$ Pemberian Nilai

Kredit, adalah:

$$
\text { 1) Untuk rasio } 100 \%
$$
atau lebih dari nilai kredit 0 .

2) Untuk setiap penurunan $0,08 \%$ nilai kredit ditambah 1 
denganmaksimum

100.

e. Faktor Likuiditas

c. Perhitungan

Cash

Rasio:

Cash

Rasio

$=\frac{\text { Aktiva Lancar }}{\text { Hutang Lancar }}+$

$100 \%$

Pemberian Nilai Kredit:

$\mathrm{NK}=($ Rasio : 0,05$) \mathrm{x}$

1(maksimum 100)

Nilai Faktor:

Nilai Faktor $=$ Bobot

ROA x NK

d. Perhitungan Rasio

LDR:

LDR

$=$

kredit yang diberikan 2!dana yang diterima

Perhitungan Nilai Kredit:

$\mathrm{NK}=(115-$ Rasio $) \mathrm{x}$

4(maksimum 100)

Nilai Faktor:

Nilai Faktor $=$ Bobot LDR x NK

f. Regresi Linier Berganda.

Analisis regresi berganda digunakan untuk meramalkan pengaruh dua atau lebih variabel prediktor (variabel bebas) terhadap satu variabel kriterium (variabel terikat) atau untuk membuktikan ada atau tidaknya hubungan fungsional antara dua buah variabel bebas (X) atau lebih dengan sebuah variabel terikat (Y).

Rumus yang digunakan adalah :

$\mathrm{Y}=\mathrm{a}+\mathrm{b}_{1} \mathrm{X}_{1}+\mathrm{b}_{2} \mathrm{X}_{2}+\mathrm{b}_{3} \mathrm{X}_{3}$

$+\mathrm{b}_{4} \mathrm{X}_{4}+\mathrm{b}_{5} \mathrm{X}_{5}+\mathrm{e}$

Keterangan:
$\mathrm{Y}_{\text {Keuangan }}=$ Kinerja

$\mathrm{a}=$ Konstanta

$\mathrm{X}_{1} \quad=$ Capital .

$\mathrm{X}_{2}=$ Asset

Quality.

$\mathrm{X}_{3}=$

Management.

$\mathrm{X}_{4}=$ Earning.

$\mathrm{X}_{5} \quad=$ Liquidity.

$\mathrm{b}_{1}-\mathrm{b}_{6}=$ Koefisien regresi parsial.

e = Hambatan.

\section{Pengujian Hipotesis}

Untuk

mengetahui

pengaruh masing-masing variabel bebas pada variabel terikat perlu dilakukan pengujian signifikansi dari masing-masing koefisien regresi 100\% yaitu dengan menggunakan Uji " $\mathrm{t}$ " dan uji " $F$ ".

Analisis Koefisien Determinasi $\left(\mathbf{R}^{2}\right)$ Analisis Koefisien determinasi digunakan untuk mengukur kebenaran menggunakan model analisis regresi dan mengukur seberapa jauh kemampuan model dalam menerangkan variasi variabel dependen. Koefisien determinasi digunakan untuk mengetahui seberapa besar prosentase sumbangan variabel bebas terhadap variabel terikat yang dapat pula dinyatakan dalam persentase.

\section{HASIL PENELITIAN DAN PEMBAHASAN \\ Analisis Regresi Berganda}

Hasil analisis regresi adalah berupa koefisien untuk masingmasing variabel independen. Koefisien ini diperoleh dengan cara memprediksi nilai variabel dependen dengan suatu persamaan (Ghozali, 2006) 
Table 4.6

Hasil uji regresi

Coefficients

\begin{tabular}{|c|c|c|c|c|c|c|c|c|}
\hline \multirow[b]{2}{*}{ Mode } & & \multicolumn{2}{|c|}{$\begin{array}{l}\text { Unstandardized } \\
\text { Coeff icients }\end{array}$} & \multirow{2}{*}{$\begin{array}{c}\text { Standardized } \\
\text { Coeff icients } \\
\text { Beta }\end{array}$} & \multirow[b]{2}{*}{$\mathrm{t}$} & \multirow[b]{2}{*}{ Sig. } & \multicolumn{2}{|c|}{ Collinearity Statistics } \\
\hline & & $\mathrm{B}$ & Std. Error & & & & Tolerance & VIF \\
\hline 1 & (Constant) & -2.591 & 2.583 & & -1.003 & .330 & & \\
\hline & ATMR & -.015 & .055 & -.084 & -4.265 & .005 & 262 & 3.810 \\
\hline & KPMM & -.044 & .355 & -.021 & -4.123 & .015 & .909 & 1.100 \\
\hline & CAR & -.035 & 109 & -.061 & -4.100 & .006 & .740 & 1.351 \\
\hline & KAP & .015 & .008 & .585 & 4.849 & .008 & .265 & 3.777 \\
\hline & PPAP & .092 & .048 & .421 & 3.936 & .007 & .560 & 1.787 \\
\hline & PM & -.018 & .082 & -1.180 & -3.214 & .018 & .200 & 7.257 \\
\hline & ROA & .025 & .105 & 1.352 & 3.242 & .008 & .100 & 3.470 \\
\hline & BOPO & $\begin{array}{l}-142 \\
-.1\end{array}$ & .118 & -315 & -4.210 & .002 & .391 & 2.560 \\
\hline & CASH & .027 & .037 & .152 & .745 & .900 & .633 & 1.579 \\
\hline & LDR & .585 & .331 & .331 & 1.768 & .095 & .756 & 1.323 \\
\hline
\end{tabular}

a. Dependent Variable: KINERJA

Sumber: Data sekunder yang diolah

Dari hasil uji tersebut persamaan regresi yang diperoleh adalah sebagai berikut:

$\mathrm{Y}=-2,591 \quad-0,015 \mathrm{X}_{1} \quad-0,044 \mathrm{X}_{2} \quad-$ $0,035 X_{3}+0,015 X_{4}+0,092 X_{5}-$ $0,018 \mathrm{X}_{6}+0,025 \mathrm{X}_{7}-0,142 \mathrm{X}_{7}+$ $0,027 \mathrm{X}_{8}+\mathrm{e}$

Berdasarkan persamaan diatas maka dapat dijelaskan sebagai berikut :

a. Nilai konstanta $-2,591$ menunjukkan nilai variabel kinerja dengan asumsi variabel yang lain bernilai nol.

b. Koefisien regresi ATMR sebesar -0,015 menunjukkan bahwa kenaikan komposisi ATMR sebesar $1 \%$ maka cenderung menurunkan ATMR sebesar $0,015 \%$.

c. Koefisien regresi KPMM sebesar -0,044 menunjukkan bahwa kenaikan komposisi KPMM sebesar $1 \%$ maka cenderung meningkatkan KPMM sebesar 0,44.

d. Koefisien regresi CAR sebesar -0,035 menunjukkan bahwa kenaikan komposisi CAR sebesar $1 \%$ maka cenderung menurunkan CAR sebesar $0,035 \%$.

e. Koefisien regresi KAP sebesar 0,015 menunjukkan bahwa kenaikan komposisi ATMR sebesar $1 \%$ maka cenderung meningkatkan KAP sebesar $0,015 \%$.

f. Koefisien regresi PPAP sebesar 0,092 menunjukkan bahwa kenaikan komposisi PPAP sebesar $1 \%$ maka cenderung meningkatkan PPAP sebesar $0,092 \%$.

g. Koefisien regresi ROA sebesar 0,180 menunjukkan bahwa kenaikan komposisi ROA sebesar $1 \%$ maka cenderung menurunkan ROA sebesar $0,180 \%$.

h. Koefisien regresi BOPO sebesar 0,142 menunjukkan bahwa kenaikan komposisi BOPO sebesar $1 \%$ maka cenderung menurunkan BOPO sebesar $0,142 \%$. 
i. Koefisien regresi Cash Ratio sebesar 0,027 menunjukkan bahwa kenaikan komposisi Cash Ratio sebesar $1 \%$ maka cenderung menurunkan Cash Ratio sebesar 0,027\%.

j. Koefisien regresi LDR sebesar 0,585 menunjukkan bahwa kenaikan komposisi LDR sebesar 1\% maka cenderung menurunkan LDR sebesar $0,585 \%$.

\section{Uji Kebaikan Model Penelitian}

Uji kebaikan model dalam penelitian ini terdiri dari Uji koefisien Determinan $\left(\mathrm{R}^{2}\right)$, Uji F dan Uji t. Hasil penelitian dapat digambarkan sebagai berikut :

\section{Uji Koefisien Determinan $\left(\mathbf{R}^{2}\right)$}

Uji koefisien Determinan $\left(\mathrm{R}^{2}\right)$

Pada intinya untuk mengukur seberapa jauh kemampuan model dalam menerangkan variasi variabel dependen. Dengan melihat Adjusted $\mathrm{R}$ Square maka dapat diketahui prosentase pengaruh semua variabel independen terhadap variabel dependen (Ghozali, 2006).

Tabel 4.7

Hasil Uji Koefisien Determinan $\left(\mathbf{R}^{2}\right)$

Model Summary

\begin{tabular}{|l|r|r|r|r|r|}
\hline Model & $\mathrm{R}$ & $\mathrm{R}$ Square & $\begin{array}{c}\text { Adjusted } \\
\text { R Square }\end{array}$ & $\begin{array}{c}\text { Std. Error of the } \\
\text { Estimate }\end{array}$ & $\begin{array}{c}\text { Durbin- } \\
\text { Watson }\end{array}$ \\
\hline 1 & $.741^{\mathrm{a}}$ & .549 & .284 & .494830725684388 & 2.885 \\
\hline
\end{tabular}

a. Predictors: (Constant), LDR, CAR, KPMM, PM, CASH, PPAP, BOPO, ATMR, KAP, $\mathrm{ROA}$

b. Dependent Variable: KINERJA

Sumber: Data sekunder yang diolah

Berdasarkan table diatas, nilai adjusted $\mathrm{R}$ square sebesar 0,284 artinya 28,4 persen variabel dependen dijelaskan oleh ketujuh variabel independen, sedangkan 72,6 persen dejelaskan oleh variabel independen lain yang tidak dimasukkan ke dalam model.

\section{Uji Simultan (Uji F)}

Uji simultan digunakan untuk mengetahui pengaruh variabel independen terhadap variabel dependen secara simultan (bersamasama). Pengujian dilakukan dengan menggunakan tingkat signifikasi 5 persen. Uji Simultan ini dilakukan dengan membandingkan nilai signifikansi alpha (Ghozali,2006).

\section{Tabel 4.8}

\section{Hasil Uji Simultan (Uji F)}

ANOVA ${ }^{b}$

\begin{tabular}{|ll|r|r|r|r|r|}
\hline \multicolumn{1}{|c|}{} & $\begin{array}{c}\text { Sum of } \\
\text { Sodel }\end{array}$ & & & & \\
\hline 1 & Reguares & df & Mean Square & F & Sig. \\
& Residual & 5.067 & 10 & .507 & 2.907 & $.039^{\mathrm{a}}$ \\
& Total & 4.163 & 17 & .245 & & \\
& 9.230 & 27 & & & \\
\hline
\end{tabular}

a. Predictors: (Constant), LDR, CAR, KPMM, PM, CASH, PPAP, BOPO, ATMR, KAP, ROA

b. Dependent Variable: KINERJA 
Berdasarkan hasil pengujian diatas, signifikansi sebesar 0,000 dengan nilai $\mathrm{F}$ hitung sebesar 2,907 lebih besar dari $\mathrm{F}$ table $=2,17$. Maka dapat disimpulkan bahwa keseluruhan variabel independen berpengaruh secara simultan terhadap variabel dependen.

\section{Uji Signifikan Parameter Individual (Uji t)}

Untuk mengetahui pengaruh variabel ATMR, KPMM, CAR, KAP, PPAP, PM, ROA, BOPO, Cash Ratio, LDR terhadap kinerja keuangan maka perlu dilakukan uji t. Hasil dari uji t dalam penelitian ini adalah sebagai berikut : (Lihat table 4.8)

1. Pengaruh variabel ATMR terhadap kinerja keuangan. Berdasarkan tabel 4.6 diatas dapat dilihat bahwa nilai $b$ untuk ATMR adalah $-0,015$ sedangkan thitung untuk ATMR sebesar $-4,265$ atau lebih besar dari nilai t-tabel 2,000 dengan nilai signifikansi sebesar 0,005 atau lebih besar dari 0,05 sehingga disimpulkan bahwa H1 diterima. Berarti dapat disimpulkan bahwa ATMR berpengaruh terhadap kinerja keuangan.

2. Pengaruh variabel KPMM terhadap kinerja keuangan . Berdasarkan tabel 4.6 diatas dapat dilihat bahwa nilai $b$ untuk KPMM adalah $-0,044$ sedangkan thitung untuk ATMR sebesar $-4,123$ atau lebih besar dari nilai t-tabel 2,000 dengan nilai signifikansi sebesar 0,015 atau lebih kecil dari 0,05 sehingga disimpulkan bahwa $\mathbf{H 1}$ ditolak. Berarti dapat disimpulkan bahwa KPMM tidak berpengaruh terhadap kinerja keuangan.

3. Pengaruh variabel CAR terhadap kinerja keuangan. Berdasarkan tabel 4.6 diatas dapat dilihat bahwa nilai $b$ untuk CAR adalah 0,035 sedangkan t hitung untuk CAR sebesar -4,100 atau lebih besar dari nilai t-tabel 2,000 dengan nilai signifikansi sebesar 0,006 atau lebih kecil dari 0,05 sehingga disimpulkan bahwa H1 ditolak. Berarti dapat disimpulkan bahwa CAR tidak berpengaruh terhadap kinerja keuangan.

4. Pengaruh variabel KAP terhadap kinerja keuangan. Berdasarkan tabel 4.6 diatas dapat dilihat bahwa nilai b untuk KAP adalah 0,015 sedangkan t hitung untuk KAP sebesar 4,849 atau lebih besar dari nilai t-tabel 2,000 dengan nilai signifikansi sebesar 0,008 atau lebih besar dari 0,05 sehingga disimpulkan bahwa H1 diterima. Berarti dapat disimpulkan bahwa KAP berpengaruh terhadap kinerja keuangan.

5. Pengaruh variabel PPAP terhadap kinerja keuangan . Berdasarkan tabel 4.6 diatas dapat dilihat bahwa nilai $b$ untuk PPAP adalah 0,092 sedangkan $t$ hitung untuk PPAP sebesar 3,936 atau lebih besar dari nilai t-tabel 2,000 dengan nilai signifikansi sebesar 0,007 atau lebih besar dari 0,05 sehingga disimpulkan bahwa H1 ditolak. Berarti dapat disimpulkan bahwa PPAP tidak berpengaruh terhadap kinerja keuangan.

6. Pengaruh variabel ROA terhadap 
kinerja keuangan. Berdasarkan tabel 4.6 diatas dapat dilihat bahwa nilai b untuk ROA adalah 0,025 sedangkan $t$ hitung untuk ROA sebesar 3,242 atau lebih besar dari nilai t-tabel 2,000 dengan nilai signifikansi sebesar 0,008 atau lebih besar dari 0,05 sehingga disimpulkan bahwa H1 ditolak. Berarti dapat disimpulkan bahwa ROA tidak berpengaruh terhadap kinerja keuangan.

7. Pengaruh variabel BOPO terhadap kinerja keuangan. Berdasarkan tabel 4.6 diatas dapat dilihat bahwa nilai $b$ untuk BOPO adalah $-0,142$ sedangkan t hitung untuk BOPO sebesar 4,210 atau lebih kecil dari nilai t-tabel 2,000 dengan nilai signifikansi sebesar 0,002 atau lebih besar dari 0,05 sehingga disimpulkan bahwa H1 ditolak. Berarti dapat disimpulkan bahwa BOPO tidak berpengaruh terhadap kinerja keuangan.

8. Pengaruh variabel Cash Ratio terhadap kinerja keuangan. Berdasarkan tabel 4.6 diatas dapat dilihat bahwa nilai $b$ untuk Cash Ratio adalah 0,027 sedangkan t hitung untuk Cash Ratio sebesar 0,745 atau lebih kecil dari nilai t-tabel 2,000 dengan nilai signifikansi sebesar 0,900 atau lebih besar dari 0,05 sehingga disimpulkan bahwa $\mathbf{H 1}$ ditolak. Berarti dapat disimpulkan bahwa Cash Ratio tidak berpengaruh terhadap kinerja keuangan.

9. Pengaruh variabel LDR terhadap kinerja keuangan. Berdasarkan tabel 4.6 diatas dapat dilihat bahwa nilai $b$ untuk LDR adalah 0,585 sedangkan t hitung untuk LDR sebesar 1,768 atau lebih kecil dari nilai t-tabel 2,000 dengan nilai signifikansi sebesar 0,095 atau lebih besar dari 0,05 sehingga disimpulkan bahwa H1 ditolak. Berarti dapat disimpulkan bahwa LDR tidak berpengaruh terhadap kinerja keuangan.

\section{Pembahasan}

\section{Pengaruh Permodalan terhadap Kinerja Keuangan}

Modal merupakan faktor yang sangat penting bagi perkembangan dan kemajuan bank serta upaya untuk tetap menjaga kepercayaan masyarakat. Bank Indonesia (BI) sebagai otoritas moneter menetapkan ketentuan mengenai kewajiban penyediaan modal minimum yang harus selalu dipertahankan setiap bank. Kecakupan modal merupakan faktor penting dalam bank dalam rangka pengembangan usaha dan menampung risiko kerugian. Bank Indonesia mendapatkan kewajiban penyediaan modal minimum yang harus selalu dipertahankan oleh setiap bank sebagai suatu proporsi tertentu dari total ATMR. Ketentuan pemenuhan permodalan minimum bank disebut juga Capital Adequacy Ratio (CAR), ketentuan CAR adalah $8 \%$. Kecuali pada saat terjadi krisis moneter pada tahun 1998, ketentuan CAR diturunkan menjadi $4 \%$. Penurunan nilai CAR tersebut dimaksudkan untuk membantu kinerja tingkat kesehatan bank. Angka ini merupakan penyesuaian dari ketentuan yang berlaku secara internasional berdasarkan standar Bank for International Settlement (BIS), agar perbankan Indonesia 
dapat berkembang secara sehat dan memiliki kemampuan bersaing dengan bank-bank internasional (Nanda, 2006).

Pengaruh variabel ATMR terhadap kinerja keuangan. Berdasarkan tabel 4.6 diatas dapat dilihat bahwa nilai $b$ untuk ATMR adalah 0,015 sedangkan $t$ hitung untuk ATMR sebesar 4,265 atau lebih besar dari nilai t-tabel 2,000 dengan nilai signifikansi sebesar 0,005 atau lebih besar dari 0,05 sehingga disimpulkan bahwa H1 diterima. Berarti dapat disimpulkan bahwa ATMR berpengaruh terhadap kinerja keuangan.

$\begin{array}{ccr} & \text { Pengaruh } & \text { variabel } \\ \text { KPMM } & \text { terhadap } & \text { kinerja }\end{array}$ keuangan . Berdasarkan tabel 4.6 diatas dapat dilihat bahwa nilai $b$ untuk KPMM adalah 0,044 sedangkan t hitung untuk ATMR sebesar 4,123 atau lebih kecil dari nilai t-tabel 2,000 dengan nilai signifikansi sebesar 0,015 atau lebih besar dari 0,05 sehingga disimpulkan bahwa H1 ditolak. Berarti dapat disimpulkan bahwa KPMM tidak berpengaruh terhadap kinerja keuangan.

Pengaruh variabel CAR terhadap kinerja keuangan. Berdasarkan tabel 4.6 diatas dapat dilihat bahwa nilai b untuk CAR adalah $-0,035$ sedangkan $t$ hitung untuk CAR sebesar $-4,100$ atau lebih kecil dari nilai t-tabel 2,000 dengan nilai signifikansi sebesar 0,006 atau lebih besar dari 0,05 sehingga disimpulkan bahwa H1 ditolak. Berarti dapat disimpulkan bahwa CAR tidak berpengaruh terhadap kinerja keuangan.

\section{Pengaruh Rasio Kualitas Aktiva Produktif terhadap kinerja keuangan}

Aktiva

produktif

sebagaimana di maksud dalam Surat Edaran Bank Indonesia No. 31/147/KEP/DIR tanggal 12 November 1998 adalah penanaman dana baik dalam rupiah atau valuta asing dalam bentuk kredit, surat berharga, penempatan antar bank, penyertaan, termasuk komitmen dan kontijensi pada transaksi rekening administratif. Kualitas aktiva produktif adalah semua aktiva dalam rupiah atau valas yang dimiliki oleh bank dengan maksud untuk memperoleh penghasilan sesuai dengan fungsinya, yaitu pemberian kredit, kepemilikan surat-surat berharga, dan penempatan dana kepada bank lain baik dari dalam maupun luar negeri terkecuali penanaman dana dalam bentuk giro atau penyertaan. (Dendawijaya:2009)

Dalam hal ini upaya yang dilakukan adalah untuk menilai jenis-jenisasset yang dimiliki oleh bank. Penilaian asset harus sesuai dengan peraturan oleh Bank Indonesia dengan membandingkan antara aktiva produktif yang diklasifikasikan terhadap aktiva produktif, kemudian rasio penyisihan penghapusan aktiva produktif terhadap aktiva produktif diklasifikasikan. Salah satu jenis dari rasio kualitas aktiva produktif adalah NPL (Non Performing Loan).

Kelangsungan kegiatan operasi bank sangat dipengaruhi pada kesiapan bank menanggung kemungkinan timbulnya risiko 
kerugian dalam kegiatan menanamkan dana ke dalam berbagai alternatif investasi khususnya dalam aktiva produktif. Untuk mengantisipasi terjadinya risiko kerugian, bank perlu membentuk penyisihan penghapusan aktiva produktif (PPAP). Apabila ternyata jumlah PPAP lebih kecil dari yang seharusnya dibentuk, maka jumlah kekurangan tersebut diperhitungkan sebagai pengurang modal inti dalam perhitungan kewajiban penyediaan modal minimum bank.

Pengaruh variabel KAP terhadap kinerja keuangan. Berdasarkan tabel 4.6 diatas dapat dilihat bahwa nilai $b$ untuk KAP adalah 0,015 sedangkan $\mathrm{t}$ hitung untuk KAP sebesar 4,849 atau lebih besar dari nilai t-tabel 2,000 dengan nilai signifikansi sebesar 0,008 atau lebih besar dari 0,05 sehingga disimpulkan bahwa H1 diterima. Berarti dapat disimpulkan bahwa KAP berpengaruh terhadap kinerja keuangan.

Pengaruh variabel PPAP terhadap kinerja keuangan . Berdasarkan tabel 4.6 diatas dapat dilihat bahwa nilai b untuk PPAP adalah 0,092 sedangkan $\mathrm{t}$ hitung untuk PPAP sebesar 3,936 atau lebih kecil dari nilai t-tabel 2,000 dengan nilai signifikansi sebesar 0,007 atau lebih besar dari 0,05 sehingga disimpulkan bahwa $\mathrm{H1}$ ditolak. Berarti dapat disimpulkan bahwa PPAP tidak berpengaruh terhadap kinerja keuangan.

\section{Rasio Manajemen (Management)}

Menurut Stoner dalam T. Hani Handoko (2003), "Manajemen adalah proses perencanaan, pengorganisasian, pengarahan dan pengawasan usaha-usaha para anggota organisasi dan penggunaan sumber daya-sumber daya organisasi lainnya agar mencapai tujuan organisasi yang telah ditetapkan."

Menurut Luther Gulick dalam T. Hani Handoko (2003), "Manajemen adalah suatu bidang ilmu pengetahuan (scince) yang berusaha secara sistematis untuk memahami mengapa dan bagaimana manusia bekerjasama untuk mencapai tujuan dan membuat sistem kerjasama ini lebih bermanfaat bagi kemanusiaan."

Unsur-unsur penilaian dalam kualitas manajemen adalah manejemen permodalan, manajemen aktiva, manajemen umum, manajemen rentabilitas dan manajemen likuiditas, yang didasarkan atas jawaban dari 100 pertanyaan yang diajukan. Penilaian terhadap faktor-faktor manajemen, meliputi penilaian terhadap komponen-komponen sebagai berikut :

a. Kualitas manajemen umum, penerapan manajemen risiko terutama pemahaman manajemen atas risiko Bank Umum atau UUS.

b. Kepatuhan Bank Umum atau UUS terhadap ketentuan yang berlaku, komitmen kepada Bank Indonesia maupun pihak lain, dan kepatuhan terhadap prinsip syariah termasuk edukasi pada masyarakat, pelaksana fungsi sosial. 


\section{d. Rasio Rentabilitas (Earning)}

Analisis rasio rentabilitas bank adalah alat untuk menganalisis atau mengukur tingkat efisiensi usaha dan profitabilitas yang dicapai oleh bank yang bersangkutan. Selain itu, rasio-rasio dalam kategori ini dapat pula digunakan untuk mengukur tingkat kesehatan keuangan bank bank. (Dendawijaya:2009)

Rentabilitas adalah kemampuan bank untuk menghasilkan keuntungan yang wajar sesuai dengan line of business. Rentabilitas suatu bank dalam analisa CAMEL ini adalah meliputi besarnya rasio laba sebelum pajak diperoleh terhadap total asset (ROA), dan rasio beban operasional terhadap pendapatan operasional bank (BOPO).

Pengaruh variabel ROA terhadap kinerja keuangan. Berdasarkan tabel 4.6 diatas dapat dilihat bahwa nilai $b$ untuk ROA adalah 0,025 sedangkan $\mathrm{t}$ hitung untuk ROA sebesar 3,242 atau lebih besar dari nilai t-tabel 2,000 dengan nilai signifikansi sebesar 0,008 atau lebih kecil dari 0,05 sehingga disimpulkan bahwa $\mathrm{H1}$ ditolak. Berarti dapat disimpulkan bahwa ROA tidak berpengaruh terhadap kinerja keuangan.

Pengaruh variabel BOPO terhadap kinerja keuangan. Berdasarkan tabel 4.6 diatas dapat dilihat bahwa nilai b untuk BOPO adalah - 0,142 sedangkan $t$ hitung untuk BOPO sebesar 4,210 atau lebih kecil dari nilai ttabel 2,000 dengan nilai signifikansi sebesar 0,002 atau lebih besar dari 0,05 sehingga disimpulkan bahwa H1 ditolak. Berarti dapat disimpulkan bahwa BOPO tidak berpengaruh terhadap kinerja keuangan.

\section{e. Rasio Likuiditas (Liquidity)}

Likuiditas adalah menunjukkan kemaampuan suatu perusahaan untuk memenuhi kewajiban pada saat ditagih, perusahaan yang mampu memenuhi kewajiban keuangannya tepat pada waktunya berarti perusahan tersebut dalam keadaan likuid. Rasio likuiditas adalah kemampuan suatu bank dalam memenuhi kewajiban jangka pendeknya secara tepat waktu Suatu bank dapat dikatakan likuid, apabila bank bersangkutan mampu membayar semua hutangnya terutama hutang jangka pendek. Dalam hal ini yang dimaksud dengan hutang jangka pendek yang ada di bank antara lain adalah simpanan masyarakat yaitu seperti tabungan, giro, dan deposito.

Dikatakan likuid jika pada saat ditagih bank mamapu membayar. Kemudian bank juga harus dapat pula memenuhi semua permohonan kredit yang layak dibiayai. Dalam penelitian ini, rasio likuiditas yang digunakan adalah Loan to Deposit Ratio (LDR).

$\begin{array}{lrrr}\text { Loan to } & \text { Deposit } & \text { Ratio } \\ \text { (LDR) adalah } & \text { rasio antara } \\ \text { seluruh jumlah } & \text { kredit yang } \\ \text { diberikan bank dengan } & \text { dana } \\ \text { yang diterima oleh bank }\end{array}$
(Lukman Dendawijaya : 2009). Rasio ini digunakan untuk mengetahui kemampuan bank dalam membayar kembali kewajiban kepada para nasabah 
yang telah menanamkan dananya dengan kredit-kredit yang telah diberikan kepada para debiturnya. Semakin tinggi rasionya, semakin tinggi tingkat likuiditasnya.

Pengaruh variabel Cash Ratio terhadap kinerja keuangan. Berdasarkan tabel 4.6 diatas dapat dilihat bahwa nilai $b$ untuk Cash Ratio adalah 0,027 sedangkan $\mathrm{t}$ hitung untuk Cash Ratio sebesar 0,745 atau lebih kecil dari nilai t-tabel 2,000 dengan nilai signifikansi sebesar 0,900 atau lebih besar dari 0,05 sehingga disimpulkan bahwa $\mathbf{H 1}$ ditolak. Berarti dapat disimpulkan bahwa Cash Ratio tidak berpengaruh terhadap kinerja keuangan.

Pengaruh variabel LDR terhadap kinerja keuangan. Berdasarkan tabel 4.6 diatas dapat dilihat bahwa nilai b untuk LDR adalah 0,585 sedangkan $\mathrm{t}$ hitung untuk LDR sebesar 1,768 atau lebih kecil dari nilai t-tabel 2,000 dengan nilai signifikansi sebesar 0,095 atau lebih besar dari 0,05 sehingga disimpulkan bahwa $\mathrm{H1}$ ditolak. Berarti dapat disimpulkan bahwa LDR tidak berpengaruh terhadap kinerja keuangan.

Adapun hasil pembahasan diatas dapat disimpulkan dalam bentuk tabel dibawah ini :

\begin{tabular}{|l|l|l|l|l|}
\hline Hipotesis & Uji t & Sig. & Hasil & Kesimpulan \\
\hline H1 & $-4,265$ & 0,005 & Signifikan & Ada pengaruh \\
\hline H2 & $-4,123$ & 0,015 & Signifikan & Ada pengaruh \\
\hline H3 & $-4,100$ & 0,003 & Signifikan & Ada pengaruh \\
\hline H4 & 4,849 & 0,008 & Signifikan & Ada pengaruh \\
\hline H5 & 3,936 & 0,007 & Signifikan & Ada pengaruh \\
\hline H6 & $-3,214$ & 0,018 & Signifikan & Ada pengaruh \\
\hline H7 & 3,242 & 0,008 & Signifikan & Ada pengaruh \\
\hline H8 & $-4,210$ & 0,002 & Signifikan & Ada pengaruh \\
\hline H9 & 0,745 & 0,900 & Tidak Signifikan & Tidak Ada pengaruh \\
\hline H10 & 1,768 & 0,095 & Tidak Signifikan & Tidak Ada pengaruh \\
\hline
\end{tabular}

\section{PENUTUP}

\section{Kesimpulan}

Berdasarkan pembahasan yang telah dikemukaan sebelumnya maka kesimpulan yang dpt diajukan adalah sebagai berikut :

1. Pengujian hipotesis dengan menggunakan uji $\mathrm{F}$ menunjukkan bahwa variabel CAMEL berpengaruh secara simultan terhadap kinerja keuangan bank.

2. Pengujian hipotesis dengan menggunakan uji t menunjukkan bahwa terdapat pengaruh antara ATMR, dan KAP, terhadap kinerja keuangan. Semakin tinggi ATMR, dan KAP maka akan semakin tinggi kinerja keuangan BPR Syariah Artha Surya Barokah Semarang.

3. Pengujian hipotesis dengan menggunakan uji t menunjukkan bahwa tidak terdapat pengaruh antara KPMM, CAR, PPAP, PM, ROA, BOPO, Cash Ratio dan LDR terhadap kinerja keuangan. Semakin tinggi KPMM, CAR, PPAP, PM, ROA, BOPO, Cash Ratio dan LDR maka akan semakin tinggi kinerja keuangan BPR Syariah Artha Surya Barokah Semarang.

\section{Keterbatasan penelitian}

Berdasarkan hasil kesimpulan diatas maka keterbatasan dalam 
penelitian ini adalah sebagai berikut :

1. Analisis dalam penelitian ini masih terbatas pada perbankan syariah. Jadi hasil penelitian ini masih tidak dapat untuk digeneralisasikan untuk perusahaan lain selain perbankan.

2. Rentang waktu yang digunakan dalam penelitian ini menggunakan data triwulan sehingga hasil penelitian belum maksimal.

3. Keterbatasan laporan keungan yang dimiliki BPR Syariah Artha Surya Barokah Semarang sehingga hasil Saran penelitian ini tidak maksmal.

Saran yang dapat dikemukaan dalam penelitian ini adalah sebagai berikut :

1) Sebaiknya pengukuran kinerja keuangan tidak hanya melalui kemampuan menghasilkan laba saja.

2) Sebaiknya menggunakan rasiorasio utama untuk memprediksi kinerja keuangan bank.

3) Sebaiknya data-data yang ada dalam directory BI dilengkapi agar para pengguna data dapat memperoleh data secara mendetail. 